\title{
İki Savaş Arası Dönemde Türkiye - Çekoslovakya İlişkilerine Genel Bir Bakış
}

A General Overview on Turkey-Czechoslovakia Relations in the Interwar Period

\section{Ali Servet Öncü}

\section{Özet}

Türkiye ve Çekoslovakya Birinci Dünya Savaşı'ndan sonra Osmanlı Devleti'nin ve Avusturya Macaristan İmparatorluğunun parçalanmasından sonra kurulmuşlar, bağımsızlıkla birlikte her iki ülkede de cumhuriyet rejimine geçilmiştir. Türkiye ve Çekoslovakya iki savaş arası dönemde antirevizyonist politikalar takip etmişler ve Avrupa'nın mevcut statükosunun devamını savunmuşlardır. Buna karşın Almanya, İtalya, Macaristan ve Bulgaristan gibi devletlerin izledikleri saldırgan politikalar bu iki devletin iki savaş arası dönemde izledikleri dış politikayı önemli ölçüde etkilemiştir. İki ülke arasındaki ilişkiler 11 Ekim 1924 tarihinde imzalanan dostluk antlaşmasıyla başlamış ve ticari antlaşmalar başta olmak üzere birçok alanda imzalanan antlaşmalar ve devam eden diplomatik temaslarla sürekli gelişerek Çekoslovakya'nın Almanya tarafından işgal edildiği 1939 yılına kadar devam etmiştir.

Anahtar Kelimeler: Türkiye, Çekoslovakya, İşbirliği, Ticaret, İkinci Dünya Savaş1

Yrd. Doç.Dr., Atatürk Üniversitesi, İIBBF, Uluslararası İlişkiler Bölümü, aliservetoncu@atauni.edu.tr

Bu makale iThenticate sistemi tarafından taranmıştır. 


\begin{abstract}
Turkey and Czechoslovakia were established with the collapse of the Ottoman Empire and Austro-Hungarian Empire after the First World War and adopted the republican regime once declaring their independence. Turkey and Czechoslovakia pursued anti-revisionist policies in the interwar period and advocated the continuation of the status quo in Europe. However, aggressive policies pursued by such states as Germany, Italy, Hungary and Bulgaria significantly influenced the interwar foreign policy of Turkey and Czechoslovakia. Turkey and Czechoslovakia relations began with the Treaty of Friendship signed on October 11, 1924, continuously improved with several agreements, particularly trade agreements and ongoing diplomatic contacts and continued until 1939 when Czechoslovakia was occupied by Germany.
\end{abstract}

Keywords:Turkey, Czechoslovakia, Cooperation, Trade, World War Two 


\section{Giriș}

Osmanlı Devleti'nin parçalanmasından sonra 29 Ekim 1923 tarihinde resmen kurulan Türkiye Cumhuriyeti, Lozan Anlaşması'nın imzalanmasından sonra Batı dünyası ile önemli ölçüde işbirliğine gitmişti. Çekoslovakya da Birinci Dünya Savaşı'ndan sonra Avrupa'da kurulan yeni devletlerden biriydi. Tıpkı Türkiye gibi Çekoslovakya da Batı Avrupa ile işbirliğine yönelmiş, özellikle dış politikasını İngiltere ve Fransa ile uyumlu bir çizgide sürdürmüştü. 1923'ten sonra Türkiye, bölgesinde etkin bir dış politika takip ederken, Avrupa politikalarını iseüç grup devlete göre belirlemiştir. Orta büyüklükte bir ülke olan Türkiye, Avrupa'daki güç dengelerine göre politikalar geliştirmek veya ittifaklara girmek arasında tercih yapmak zorunda kalmış, yapacağı ittifaklar uydulaşmasına neden olabileceği için birinci yolu seçmiştir. İki savaş arası dönemde İngiltere - Fransa, Almanya - İtalya ve Sovyet Sosyalist Cumhuriyetler Birliği Avrupa'da öne çıkan üç grup devletti. Türkiye, birinci grup devletlerle yakınlaşırken, ikinci gruba ise siyaseten uzak durmuştur. Türkiye'nin İkinci Dünya Savaşı'nın ilk yıllarına kadar SSCB ile ilişkileri ise hiçbir dönemde olmadığı kadar iyi olmuştur. (Akdevelioğlu ve dĭg., 2001: 253-254).

Makalede Birinci Dünya Savaşı'ndan sonra kurulan ve benzer dış politikalar takip eden iki devletin iki savaş arası dönemde ilişkilerinin nasıl başladığı ve neden uyumlu bir şekilde devam ettiği ve aralarındaki dostluğun Avrupa barışına nasıl hizmet ettiği soruları ele alınıp bunlara cevap aranmaya çalışılacaktır. Makalenin yazımında Başbakanlık Cumhuriyet Arşivi belgeleri, Resmi Gazete nüshaları, TBMM Zabıt Cerideleri, Devlet İstatistik Enstitüsü verileri, yine o döneme ait günlük gazeteler, hatıratlar ve araştırma eserlerinden faydalanılmış, kronolojik bir şekilde ortaya konulan gelişmeler yorum ve analizlerle desteklenmeye çalışılmıştır.

\section{Çekoslovakya'nın Bağımsızlığını İlan Etmesi ve İki Savaş Arası Dönemde Çekoslovakya Dış Politikası}

Birinci Dünya Savaşı'nın son yılarında Avusturya Macaristan İmparatorluğu'nda yaşayan Çekler, diğer azınlıklarla birlikte bağımsızlık için harekete geçmişler, Thomas Masaryk, Edouard Beneş ve Rastislav Stefanik gibi liderler 18 Ekim 1918'de Paris'te Çekoslovak Milli 
Konseyi'ni kurmuşlardır. Avusturya Macaristan İmparatoru Charles, dağılmanın önüne geçmek için aynı tarihte yayınladığı bildiri ile azınlıkların bir federasyon içinde özerk yapılar olarak örgütleneceklerini ilan etmiş, fakat azınlıklar bu kararı benimsememişlerdir (Renouvin, 1982: 485-486 Armaoğlu, 1996: 180).24 Ekim 1918 tarihinde hükümet son bir ümit olarak ulusal devletlerin serbestçe kurulabildiği fakat ortaklaşa bir yürütme organılyla birbirlerine bağlı olduğu bir sistem üzerinde durmuştur. Fakat bu çaba da sonuç vermemiş, Prag Ulusal Konseyi 28 Ekim 1918'de Çekoslovakya Cumhuriyeti'ni ilan etmiş, Prag ve Paris grupları anlaşarak,Cumhurbaşkanlığına Masaryk'i, Başbakanlığa Karel Kramar'1, Dışişleri Bakanlığına da Beneş'i getirmişlerdir. 10 Eylül 1919'da imzalanan Saint Germain Antlaşması'nda da Çekoslovakya'nın Bohemya-Moravya, Avusturya Silezyası'nın bir bölümü ve Macaristan'ın kuzey parçasından oluşması kararlaştırılmıştır (Jelavıch, 1987: 486-487, Üçok, 1978: 231, Renouvin, 1982: 487-488, Armaoğlu, 1996: 180-181).

$\mathrm{Bu}$ yıllarda Doğu Avrupa ülkelerinde faşist diktatörlükler iktidardayken, Çekoslovakya demokrasiyi başarılı bir şekilde uygulamıştır. Bunda Çek liderlerin demokrat kimlikleriyle birlikte, ülkelerini sanayileştirmek için başlattıkları hamle de etkili olmuştur (Sander, 2008: 241, Armaoğlu, 1996: 181). Avusturya Macaristan İmparatorluğunun endüstri tesislerinin bir bölümünün bulunduğu Çekoslovakya, bir tarım ülkesi değildi. Bu durum Çekoslovakya'yı ham maddeleri ithal ve mamul maddeleri ihraç için pazar aramak zorunda bırakmış, Çekoslovakya da Orta Avrupa ülkelerinin istikrarsız piyasaları yerine, Batı Avrupa ülkelerine yönelmiş, bu da Batı Avrupa devletleriyle yakınlaşmasına neden olmuştur. Ülkede altı buçuk milyonluk Çek nüfusunun yanında, üç milyon yüz bin Alman, iki milyon iki yüz bin Slovak, yedi yüz kırk yedi bin Macar, dört yüz elli dokuz bin Ruten, yetmiş altı bin Polonyalı ve yüz seksen bin Yahudi yaşıordu. Çekoslovakya liberal yaklaşımlarıyla azınlıkları memnun etmeye çalışmışsa da ayrılıkçılığı engelleyememiştir. Rutenlerin otonomi istekleri, en güçlü azınlık olan ve Südetler bölgesinde yaşayan Almanlar ile Çekler arasındaki düşmanlık, rekabet ve Almanların 1920 anayasası ile azınlık durumuna düşürülmelerini kabullenememeleri Çekoslovakya'yı sürekli uğraştırmıştır. Almanlar, Çekoslovakya'nın Fransa, Yugoslavya ve Romanya ile işbirliğinden rahatsız olmuşlar ve Berlin'e yönelmiş- 
lerdir. Yine Çekoslovakya sınırları oluşturulurken Teschen bölgesinin Polonya ile paylaşılması iki tarafı da tatmin etmemiş ve anlaşmazlığa sebep olmuştur (Macmillan, 2004: 239-240, Armaoğlu, 1996: 181). Çekoslovakya'nın bir diğer sorunu da Çekler ve Slovaklar arasındaki çekişmeydi. İmparatorluk döneminde Çekler, Avusturya idaresinde yaşamış aydın ve kültürlü insanlardı. Slovaklar ise Macaristan idaresinde ve kırsalda yaşamışlardı. Her ikisi de Katolik olmasına rağmen Çekler anti-klerikal, Slovaklar ise koyu Katoliktiler. Çekoslovakya'da eriyeceklerini düşünen Slovaklar, hoşlanmamalarına rağmen Macaristan'a katılmak için çaba harcıyorlardı (Armaoğlu, 1996: 182).

İki savaş arası dönemde Fransa ve Çekoslovakya revizyonist devletlere karşı ortak bir dış politika yürütmüşlerdir. Revizyonist politikalar izleyen Macaristan, Çekoslovakya için en büyük tehditlerden birisiydi. Çekoslovakya,Versailles düzeninin yıkılması ve Macaristan'da Habsburg İmparatorluğunun yeniden kurulması, dağılmasına sebep olabileceği için Fransa, Romanya ve Yugoslavya'ya yaklaşmıştır (Armaoğlu, 1996: 182). Çekoslovakya, Romanya ve Yugoslavya'yı bir araya getiren Küçük Antant fikri Dışişleri Bakanı Beneş’e aitti. Birinci Dünya Savaşı sonunda Romanya ve Yugoslavya, Macaristan ve Bulgaristan aleyhine büyük miktarda toprak kazanmışlardı. Beneş, 1919 yılı Aralık ve 1920 yılı Ocak aylarında Yugoslavya ve Romanya’ya ittifak önermiş, Çekoslovakya ve Yugoslavya 14 Ağustos 1920'de Macaristan'a karşı anlaşmışlardır. Bu ittifakın SSCB ve Bulgaristan'a da karşı olmasını isteyen Romanya, Çekoslovakya'nın bu teklifi kabul etmemesi üzerine ittifaka katılmamış fakat eski Avusturya Macaristan İmparatoru Charles'ın Macaristan'da hükümdarlığı ele geçirmek için yaptığ 1 girişimlerden çekinip 23 Nisan 1921'de Macaristan'a karş1 Çekoslovakya ile ittifak antlaşması imzalamıştır. Bunu 7 Haziran 1921 'de Romanya ve Yugoslavya arasında imzalanan antlaşma ve üç ülke arasındaki askeri işbirliği antlaşmaları izlemiştir. Fransa ise 25 Ocak 1924'de Çekoslovakya, 10 Haziran 1926'da Romanya ve 11 Kasım 1927'de Yugoslavya ile imzalamış olduğu antlaşmalarla bu ülkeleri kendisine bağlamıştır. Küçük Antant 21 Mayıs 1929'da imzalanan bir antlaşma ile süreli olmaktan çıkmış, 16 Şubat 1933tarihinde de devamlı bir statüye kavuşmuştur (Kennedy, 2001: 338, Armaoğlu, 1996: 188-189). 
Fransa, İngiltere, İtalya ve Çekoslovakya 1922 yılı Ekim ayında Avusturya ile Cenevre Protokolü'nü imzalayıp bu devletin Almanya ile birleşmeye yol açacakşekilde ekonomik ve mali anlaşmalar yapmasının önüne geçmişlerdir (Armaoğlu, 1996: 178). Yine yukarıda da ifade edildiği gibi Fransa ile Çekoslovakya 25 Ocak 1924'de bir anlaşma imzalayarak Almanya ile Avusturya'nın birleşme çabalarına karşı birlikte hareket etmeyi, güvenlikleri ve barış antlaşmalarının uygulanmasındaki sorunları beraberce çözmeyi kararlaştırmışlardır (Esmer, 1953: 9). 16 Ekim 1925 tarihinde imzalanan Locarno Antlaşmaları da Çekoslovakya'nın Fransa ile birlikteliğinin bir göstergesidir. Locarno'da Almanya, Belçika, Fransa, İngiltere ve İtalya arasında imzalanan bir antlaşmayla Almanya'nın Fransa ve Belçika ile sınırlarının kesinliği kararlaştırılmış, İngiltere ve İtalya bu sınırların statüsünü garanti etmişlerdir. Ayrıca Almanya ile Fransa, Belçika, Polonya ve Çekoslovakya arasında tahkim sözleşmeleri yapılmıştır. İlk antlaşmada Almanya sadece batı sınırları hakkında garanti verip, aynı garantiyi Polonya ve Çekoslovakya için vermediğinden Fransa bu devletlerin Almanya ile olan sınırlarını garanti etmiştir (Kıssınger, 2000: 258-259, Cevizliler ve Öncü, 2013: 316-325). Fransa ve Çekoslovakya Locarno Anlaşmalarıyla başlayan barış döneminin devamı olan Briand-Kellogg Paktı'nı ABD, İngiltere, Almanya, Polonya, İtalya, Belçika ve Japonya ile birlikte 27 Ağustos 1928'de imzalamışlar, Avrupa ve dünya barış1 için oluşturulan bu birlikteliğe kısa bir sürede altmış devlet daha destek vermiştir (Langlois ve diğ., 2000: 112). Çekoslovakya bu dönemde Alman revizyonizmine karşı SSCB ile debirlikte hareket etmiş, iki devlet 16 Mayıs 1935 tarihinde karşılıklı yardım paktı imzalamışlardır. FakatSovyetler Birliği, pakta koyduğu bir şart ile Alman saldırısı karşısında Fransa'nın da yardıma gelmesi şartıyla Çekoslovakya'ya yardımı kabul etmiştir (Potyemkin ve diğ., 2009: 220). İki savaş arası dönemin başından itibaren devam eden Fransa Çekoslovakya birlikteliği Fransa'nın 1930'lar boyunca Orta ve Doğu Avrupa'daki etkinliğinin gün geçtikçe azalmasıyla dağılmaya başlamıştır. Fransa 1920'lerin başından itibaren Çekoslovakya'ya verdiği garantileri Alman işgali sürecinde işletmemiş bu durum Çekoslovak devlet adamlarınca ihanet olarak görülmüş ve İkinci Dünya Savaşı'ndan sonra SSCB'ye daha sıcak bakmalarına neden olmuştur (Lee, 2002: 183, Sander, 2008: 241-242). 
Görüldüğü üzere Çekoslovakya iki savaş arası dönemde doğu ve batı sınırlarını revizyonist devletlere karşı korumak için çeşitli ittifak sistemleri içerisine girmiş ve bu politika Almanya tarafından parçalanmasına ve işgal edilmesine kadar başarıyla devam etmiştir.

\section{Türkiye Çekoslovakya İlişkilerinin Başlaması}

1923 yılında Çekoslovakya'nın Bern Büyükelçisi ve Milletler Cemiyeti'ndeki temsilcisi Rober Felbder, hükümeti tarafından Türkiye ile dostluk antlaşması imzalaması için görevlendirilmiştir. Lozan Konferansı'nda Hariciye Vekili İsmet Paşa'yla görüşen Felbder, antlaşmanın Lozan'da imzalanmasını önermiş, fakat Türk heyeti, antlaşmayı, konsolosluk ve ticaret anlaşmalarını da ekleyip İstanbul'da imzalamayı uygun görmüştür. Lozan Konferansı'ndan sonra Çekoslovak Hükümeti, TBMM Hükümeti'nin Bern Maslahat güzarlığına müracaat ederek görüşmelere başlamak istediğini bildirmiştir (BCA, 30..10.0./218.474..14., Belge No:1.). Aynı günlerde TBMM Hükümeti de dış ticaretin canlandırılması için harekete geçmiş, Türkiye'nin ticari ilişkilerinin yoğun olduğu ABD, İngiltere, Hollanda, Almanya, Fransa, İtalya, Avusturya ve Çekoslovakya gibi ülkelerde konsolosluklar açılması için çalışmalara başlanmıştır (BCA, 30..10.0.0/ 129.930..2., Belge No:1.)

Türkiye ile Çekoslovakya arasındaki dostluk antlaşması Hariciye Vekâleti Müsteşarı Tevfik Kamil Bey ve Çekoslovakya temsilcisi Rodolf Svetlik tarafından 11 Ekim 1924'te Ankara'da imzalanmıştır. Antlaşmada iki devlet arasında bozulmayacak bir dostluğun kurulacağı, iki tarafın devletler hukuku esaslarına uygun olarak diplomatik ilişkiler kurmaları ve diplomatik temsilcilerin karşılıklılık şartıyla iki ülkede devletler hukuku kuralları çerçevesinde kabul göreceği kararlaştırılmıştır. Ayrıca konsolosluk, ticari ilişkiler, iskân ve ikamet şartlar1 ve bazı adli konularda iki taraf yetkililerinin birbirlerine yapacakları yardımı, karşılıklılık esaslarına ve devletlerarası hukuk kurallarına uygun olarak düzenlemeleri kararlaştırılmıştır (Resmi Gazete 20 Nisan 1925, S. 95: 99, Vatan 12 Ekim 1924: 3, Tevhid-i Efkâr 12 Ekim 1924: 2). Cumhurbaşkanı Mustafa Kemal Paşa, TBMM'nin ikinci döneminin üçüncü yasama yılının açılış konuşmasında bu antlaşmaya da değinmiş ve imzalanmasından duyduğu memnuniyeti dile getirmiştir (TBMM Zabıt Ceridesi, 1 Kasım 1924, 1975:4). 
Dostluk Antlaşması'nın imzalanmasından sonra, 16 Haziran 1925 tarihinde eski Maarif Vekili Vasıf Efendi, Prag'a Fevkalade Murahhas ve Orta Elçi olarak gönderilmiştir (Şimşir, 1993: 571). Cumhurbaşkanı Masaryk, Vasıf Bey'in güven mektubunu verdiği törende Çekoslovakya Hükümetinin ilişkilerin geliştirilmesi konusundaki samimiyetine güvenebileceğini yine iki ülkenin dostluk antlaşmasından büyük beklentilerinin olduğunu söylemiştir. Masaryk ayrıcaVasıf Bey'in ilişkilerin ekonomi üzerinden geliştirilmesi gerektiği düşüncesine katıldığını ve imzalanan antlaşma ile ekonomik sahada da geniş bir faaliyet imkânının doğduğunu vurgulamıştır (Şimşir, 1993: 572). Vasıf Bey'in atanmasından birkaç ay sonra Prag da, Madrid Elçisi Miloş Kobr'u Olağanüstü Temsilci ve Orta Elçi sıfatıyla Ankara'ya göndermiştir. Masaryk konu ile ilgili olarak Mustafa Kemal Paşa’ya yazdığı mektupta oluşturulan güven ortamını ve uyumu daha da güçlendirmek için niteliklerine inandığı Kobr'u Ankara'ya tayin ettiğini yazmıştır. Kobr, 18 Ocak 1926'da güven mektubunu sunup,karşılıklı dostluğu ve güveni geliştirmeyi hedefleyen bu görevi memnuniyetle üstlendiğini söylemiştir. İki ülke ilişkilerinin yakınlaşacağından emin olduğunu belirten Kobr, her iki milletin birbirlerini daha iyi anlamaları için yoğun ve ortak bir çalışmanın gerekli olduğunu ve iki millet arasındaki uyumun sağlanması için birbirlerinin iç dünyalarını anlamalarının önemini vurgulamıştır. Kobr, iki ülkenin yeniden yapılanmalarına sebep olan liberal ve demokratik ilkelerin, dostluk ve güvenin teminatı olduğunu ve bu ilkelerin dostluk bağlarının sıkılaştırılmasına da katk1 sağlayacağını belirtmiştir (Şimşir, 1993: 572-574). Cumhurbaşkanı Mustafa Kemal de özgürlük ve demokrasi ilkelerinin, insanlığın ilerlemesi için çalışma arzusunun ve karşılıklı ticari çıkarların iki ülkenin uyumlu bir şekilde çalışmasına zemin hazırlayacağını söylemiştir (Şimşir, 1993: 574-575). İki ülke arasındaki ilişkiler kısa bir süre içerisinde ileri noktalara gelmiş, Türkiye, Çekoslovakya'nın önemli sanat ve ticaret merkezlerinden Bratislava şehrinde Fahri Konsolosluk açmış, 26 Aralık 1928 tarihinde bu göreve Zosepf Reisner atanmıştır (BCA, 30..18.01.02/ 1.11..15., Belge No:1).

1927 yılında her iki ülkede cumhurbaşkanlığı seçimleri yapılmıştır. Her iki lider de tekrar göreve seçildikten sonra birbirlerini kutlayıp ilişkilerin devamı yönündeki iradelerini ortaya koymuşlardır (Şimşir, 1993: 576-577). İki ülke arasındaki dostane ilişkiler Masaryk'in 
yerine seçilen Beneş döneminde de devam etmiştir. 18 Aralık 1935'de cumhurbaşkanı seçilen Beneş'i ilk kutlayan liderlerden birisi Atatürk olmuş, Beneş de seçildikten bir süre sonra Dışişleri Bakanı Aras'1 Çekoslovakya'ya davet ederek Türkiye ile ilişkilere verdiği önemi göstermiştir (Şimşir, 1993: 593, Aras, 2003: 71).

Türkiye Çekoslovakya ilişkileri, Çekoslovakya'nın 15 Mart 1939 tarihinde Almanya tarafindan işgaline kadar sorunsuz devam etmiştir. Prag Elçisi Yakup Kadri Karaosmanoğlu'nun 27 Mart 1936 tarihinde Hariciye Vekâletine gönderdiği yazı ikili ilişkilerin durumunu göstermesi açısından önemlidir. Karaosmanoğlu, Dışişleri Bakanı Krofta ile yaptığı görüşmede Bakanın birçok defalar aralarındaki dostluğu daha da derinleştirmek istediklerinden bahsettiğini, Beneş ile yaptığı görüşmede de Beneş'in Türkiye'nin dostluğuna önem verip, kalkınma hamlesine gıpta ile baktığını, Atatürk ve İnönü'den de övgüyle bahsettiğini yazmıştır (Şimşir, 1993: 596-597).

Dostluk Antlaşması'ndan sonra Çekoslovakya ile ilişkilerini derinleştirmek isteyen Türkiye, ikamet ve ticaret anlaşmaları yapmak için harekete geçmiştir. Yapılan müzakerelerden bir sonuç alınamayınca 21 Ağustos 1925 tarihinden itibaren geçerli olacak bir modusvivendi $^{1}$ anlaşması imzalanmıştır (BCA, 30..18.01.01/ 017.94..3., Belge No:1). İki ülke arasında bir ticaret anlaşması imzalanması için görüşmeler 1926 yılında tekrar başlamış, Bakanlar Kurulu 31 Ocak 1926'da Belçika Hükümetiyle ticaret ve ikamet anlaşmaları yapmak için bu ülkeye giden heyetin Çekoslovakya ve İsveç hükümetleriyle de benzer anlaşmalar yapmak için temas kurmasını kararlaştırmıştır (BCA, 30..18.1.1/ 17.89..7., Belge No:1). Yapılan görüşmeler ve Çekoslovakya Hükümeti'nin ticaret anlaşmasına ait projeyi görüşmeye hazır olduğunu bildirmesi üzerine Bakanlar Kurulu 21 Şubat 1926 tarihinde, ticaret anlaşması imzalanıncaya kadar 21 Ağustos 1925'de imzalanan modusvivendinin altı ay uzatılmasına karar vermiştir (BCA, 30..18.01.01/ 017.94..3., Belge No:1). Çekoslovakya ile başlayan gö-

1 Geçici anlaşma anlamına gelen bir sözcük olup, özellikle kısa süreli ticaret veya gümrük konuları ile ilgili ikili anlaşmaları ifade etmek için kullanılmaktadır. Ülke Arıboğan, Gülden Ayman, Beril Dedeoğlu, Uluslararası İlişkiler Sözlüğü,(der:Faruk Sönmezoğlu), İstanbul 2010, s.487. 
rüşmelerin altı aylık uzatmanın bitmesinden sonra da sonuçlanmaması modusvivendinin 29 Ağustos 1926 tarihinde altı ay daha uzatılmasına sebep olmuş, iki ülke arasındaki görüşmeler ise 31 Mayıs 1927'de Ticaret ve İkamet Anlaşmalarının imzalanmasıyla sonuçlanmıştır (BCA, 30..18.01.01/ 020.55..13., Belge No:1, BCA, 30..18.01.01/26.67..7., Belge No:1, BCA, 30..18.01.01/ 26.67..8., Belge No:1, Resmi Gazete 12 Ocak 1928, S. 786: 4621- 4624, Resmi Gazete 22 Ocak 1928, S. 794: 4662-4667). Fakat bu anlaşmanın 1929 yılında fesh edilmesinden sonra Türkiye, yeni bir anlaşma için görüşmelere başlanmasını teklif etmiştir. Çekoslovakya ise görüşmelere hazır olduğunu ancak yapılacak anlaşmanın yürürlüğe gireceği tarihin Türkiye'nin yeni gümrük tarifelerini belirleyecek yasanın henüz kabul edilmemesi yüzünden uzayabileceğini ve iki ülke meclislerinin toplanmasına kadar geçecek sürede yürürlüğe giremeyeceğini savunmuş, şimdilik bir modüsvivendi yapılmasını teklif etmiştir. Bakanlar Kurulu ise 17 Nisan 1929'da, görüşmelere başlanılmasının önünde bir engelin olmadığını ve ancak yapılacak anlaşmanın onaylanmasının gecikmesi halinde bir modüsvivendi imzalanabileceğine karar vermiş, Çekoslovakya elçisinin, fesh edilen anlaşma üzerinden Ağustos ayından sonra bir modüsvivendi yapılması teklifinin de ret edilmesini kararlaştırmıştır (BCA,30..18.01.02/3.23..7., Belge No:1). Gümrük Tarifesi Kanunu 1 Haziran 1929'da kabul edilmesine rağmen Ticaret ve İkamet Anlaşmaları imzalanamamış, bunun üzerine iki ülke arasında 19 Eylül 1929 tarihinde bir modüsvivendi anlaşması yapılmıştır (TBMM Zabit Ceridesi, 1 Haziran 1929: 207218, 231-233, BCA, 30..18.01.02/ 45.34..9., Belge No:1). Nihayet 17 Ocak 1931 'de ticari ilişkiler açısından çok önemli olan Ticaret ve Seyr-i Sefain Mukavelenamesi imzalanmış, (Resmi Gazete 6 Nisan 1931, S.1767: 371-377), fakat bu antlaşma da teati edilmediğinden yürürlüğe girememiştir (Yavuz, 1976: 105). İki ülke yeni bir anlaşma için tekrar görüşmelere başlamış ve Ticaret Antlaşması ve merkez bankalarının bu antlaşmaya uygun olarak yaptıkları Kriling Anlaşması ${ }^{2} 3$

2 Kliring, denkleştirme veya mahsup anlamlarına gelmektedir. Uluslararası ticarette malın malla değişimini ifade eden, fakat takastan biraz daha geliştirilmiş bir yöntemdir.Kliringde ithalatçı ve ihracatçıların birbirlerini arayıp bulmak ve anlaşma yapmak gibizahmetli ve zaman alıcı yollara başvurmalarına gerek yoktur. Kliring Anlaşmasına göre karşılıklı olarak hesapları tutmak ve denkleştirmeyi sağlamak amacıyla merkez bankası veya kliring ofisi gibi kuruluşlar görevlendirilmiştir. Halil Seyidoğlu, Ulusla- 
Mart 1934'de imzalamışlardır. (BCA, 30..18.01.02/ 43.13..16., Belge No:1). Bu anlaşmadan çok kısa bir süre sonra da iki ülke 17 Eylül 1929 tarihinde yapılmış olan modüsvivendinin yerine geçmek ve 15 Mayıs 1934 tarihinde yürürlüğe girmek üzereyeni bir modüsvivendi imzalamışlardır (BCA, 30..18.01.02/ 45.34..9., Belge No:1, Resmi Gazete 28 Şubat 1947, S. 6544: 11942).

3 Mart 1934 tarihinde imzalanan anlaşmanın süresinin bitmesinden sonra Bakanlar Kurulu 27 Mart 1936'da aldığı kararla yeni bir ticaret anlaşması için Prag'da yapılacak görüşmelerin Prag Elçisi Yakup Kadri Karaosmanoğlu'nun başkanlığında ve Dışişleri Bakanlığı Ticaret Dairesi Şefi ve İktisat Vekâleti müşavirinden oluşan heyet tarafindan yürütülmesine karar vermiştir (BCA, 30..18.01.02/ 63.23..17., Belge No:1). Yapılan görüşmelerden sonra yeni Ticaret Anlaşması 12 Mayıs 1936 tarihinde imzalanmış (Resmi Gazete, 18 Şubat 1937, S. 3537 : 7698, Ulus 13 Mayıs 1936: 2, Akşam 13 Mayıs 1936: 2), 18 Ocak 1938 tarihinde ise Ankara'da, bu anlaşmaya bağlı listelerde değişiklik yapılarak iki ülke arasındaki mal trampasını yeni şartlara göre daha da genişletmek için ek bir protokol yapılmıştır (BCA, 30..18.1.2/ 82.8..9., Belge No:1, Resmi Gazete, 22 Nisan 1938, S. 3839: 9733-9736). Yine 7 Nisan1938 tarihinde Ticari Mübadeleleri Tanzime Mütedair Anlaşma ve Ekleri ve Türkiye ile Çekoslovakya Menşeli Malların Fiyatlarının Ödenmesi Hakkında her iki devletin merkez bankaları arasında anlaşma imzalanmıştır (BCA, 30..18.1.2/ 84.62..13., Belge No:1, Resmi Gazete, 28 Haziran 1938, S. 3945: 10112, Ökçün ve Ökçün, 1974: 186-187, Akşam 7 Nisan 1938: 2).

İki ülke arasında diplomatik ilişkilerin başlamasından sonra ikili ilişkilerde, ticari anlaşmalar büyük bir yer işgal etmiştir. Bunda iki ülkenin arasında siyasi bir meselenin olmaması ve ilişkilerin sorunsuz devam etmesinin büyük payı vardır. Burada dikkati çeken bir başka konu iseticari anlaşmaların müzakerelerinin uzun ve çetin geçmesidir. Ayrıca ticari anlaşmaların süreleri zamanın şartlarına göre yenilenmeleri için kısa tutulmuş, yine modüsvivendi iki devlet arasındaki ticari ilişkilerde başvurulan bir yöntem olmuştur.

rarası İktisat Teori Politika ve Uygulama, İstanbul 2009, s. 722. 
Tablo 1. 1925-1938 Yılları Arasında Türkiye'nin Çekoslovakya'ya İhracat ve Çekoslovakya'dan İthalat Rakamları (Türk Lirası Olarak)

\begin{tabular}{||l|l|l||l|l|l|}
\hline Ylllar & İhracat & İthalat & Yıllar & İhracat & Ithalat \\
\hline $\mathbf{1 9 2 5}$ & 26.590 & 10.192 .337 & $\mathbf{1 9 3 2}$ & 1.251 .151 & 3.734 .558 \\
\hline $\mathbf{1 9 2 6}$ & 31.308 & 16.484 .870 & $\mathbf{1 9 3 3}$ & 3.676 .023 & 3.466 .093 \\
\hline $\mathbf{1 9 2 7}$ & 5.556 .770 & 13.698 .732 & $\mathbf{1 9 3 4}$ & 679.741 & 4.650 .344 \\
\hline $\mathbf{1 9 2 8}$ & 7.181 .759 & 13.598 .028 & $\mathbf{1 9 3 5}$ & 3.043 .111 & 3.853 .812 \\
\hline $\mathbf{1 9 2 9}$ & 15.458 .482 & 3.645 .089 & $\mathbf{1 9 3 6}$ & 4.012 .343 & 3.626 .743 \\
\hline $\mathbf{1 9 3 0}$ & 1.143 .009 & 8.181 .536 & $\mathbf{1 9 3 7}$ & 6.092 .916 & 3.006 .152 \\
\hline $\mathbf{1 9 3 1}$ & 3.063 .359 & 5.952 .271 & $\mathbf{1 9 3 8}$ & 4.997 .640 & 5.776 .481 \\
\hline
\end{tabular}

Türkiye ve Çekoslovakya arasında yapılan ticari anlaşmalar dış ticaret rakamlarını olumlu etkilemiştir. Türkiye ihracatını her yıl istikrarlı olarak artırmış, Çekoslovakya da ihracat rakamlarında belli bir istikrarı yakalamıştır. İmzalanan antlaşmalar 1929 Dünya Ekonomik Bunalımına kadar her iki ülke için büyük avantajlar sağlamıştır. Fakat Büyük Buhran iki ülke arasındaki dış ticarete büyük bir darbe vurmuştur. Türkiye, 1929 yılında Çekoslovakya'ya olan 15.458.482 liralık ihracatını bir daha yakalayamamış, Çekoslovakya da kriz öncesi ulaştığı 16.484.870 liralık ihracata bir daha ulaşamamıştır (1925 Senesine Mahsus Ticaret-i Hariciye İstatistiki, Harici Ticaret İçin Yıllık İstatistik Y11 1926 Kısım II, 1929: 197, Harici Ticaret İçin Yıllık İstatistik Yıl 1927 Kısım II, 1929: V, XXVIII, Harici Ticaret İçin Yıllık İstatistik Y1l 1928 Kısım II: 1930: 181, Harici Ticaret İçin Yıllık İstatistik Y11 1929 Kısım II, 1931: 231,271, Harici Ticaret İçin Y1llık İstatistik Y1l 1930 Kısım II, 1932: 260-261, Harici Ticaret Y1ll1k İstatistik Y11 1931 K1sım II, 1934: 1, Harici Ticaret Y1llık İstatistik Y1l 1932 Kısım II, 1934: 1, Harici Ticaret 1933 Yıllık İstatistik Kısım 2 No 1, 1935: 143-145, Harici Ticaret Yıllık İstatistik 1938 Kısım- 2, 1939: III, X).

Yolunda giden ilişkiler farklı alanlarda da işbirliklerini gündeme getirmiştir. 8 Aralık 1926 tarihli bir kararname ile konsolosluk ve adli konularda anlaşma yapmak için görüşmelere başlanmış fakat bir sonuç alınamamıştır (BCA, 30..18.1.1/ 022.75..7., Belge No:1). 1930 y1lında 
ise Türkiye'nin Almanya, Çekoslovakya ve Bulgaristan ile suçluların iadesi ve adli yardımlaşma anlaşmaları imzalaması gündeme gelmiş, 22 Ağustos 1930 tarihinde Prag'ta Çekoslovakya ile Türkiye arasında Suçluların İadesi ve Ceza İşlerinde Adli Yardım ve Medeni ve Ticari Hususat-1 Kazaiyeye Mütedair Karşılıklı İlişkiler Hakkında antlaşmalar imzalanmıştır (BCA, 30..18.01.02/ 11.40..9., Belge No:1, Resmi Gazete, 9 Temmuz 1932, S.2145: 1695-1697, 1699-1702). Bundan bir süre sonra Çekoslovakya ile Adli Tesviye, Hakem ve Uzlaşma Anlaşmaları imzalanması gündeme gelmiş, Bakanlar Kurulu hazırlanan anlaşma metnini inceleyerek onaylamış, anlaşmayı imzalaması için Dışişleri Bakanı Tevfik Rüştü Aras'a yetki verilmiş, (BCA, 30..18.01.02/ 18.15..4., Belge No:1) anlaşma Aras ile Milos Kobr arasında 17 Mart 1931 tarihinde Ankara'da imzalanmıştır (BCA, 30..18.1.2/ 28.37..18., Belge No:1, Resmi Gazete, 5 Ağustos 1931, S. 1865: 727-728).

\section{Almanya'nın Çekoslovakya'yı İşgali Karşısında Türkiye}

Almanya Münih Konferansı'nda alınan kararlar gereği Ekim 1938'de Çekoslovakya'nın Südetland bölgesini işgale başlamıştır (Uçarol, 2010: 650, Sander, 2008: 59-60). İşgalle iki milyon sekiz yüz bin Alman ve yedi yüz bin Çek ülkeden kopmuş, Polonya da 1 Ekim 1938 tarihinde Çekoslovakya'ya ait Teschen ve Bohumin bölgelerini işgal etmiş, 2 Kasım 1938'de de Slovakya'nın güneyi Almanya'nın onayıyla Macaristan'a bırakılmıştır. Dolayısıyla Münih Anlaşması'ndan sonra ülke dağılmaya başlamış, azınlıklar muhtariyet için hareketlenmiş, hükümet 19 Kasım 1938'de çıkardığ 1 bir kanunla federal sistemi kabul etmiş, fakat dağılmayı önleyememiştir. Slovakya ve Rutenya otonomi kazanmış, Almanya, Bohemya ve Moravya'da bulunan üç yüz elli bin kadar Alman'ı kendileriyle birleşmeleri için kışkırtmaya başlamıştır. Böylece Çeklerle Slovakların ortak olarak sadece orduları, dışişleri ve maliyeleri kalmış, Cumhurbaşkanı Beneş 5 Ekim 1938 günü istifa etmiş, 30 Kasım'da Hacha cumhurbaşkanı seçilmiştir. Hitler'in desteği ile Tiso 14 Mart 1939'da Slovakya'nın bağımsızlığını ilan edip Almanya’nın himayesine girmiştir. Aynı gün Hitler,Hacha'yı Berlin'e davet ederek baskı altında Çekoslovakya'nın Almanya'nın kontrolüne bırakıldığına dair bir belge imzalatmış, Alman orduları 14 Mart'ı 15 Mart'a bağlayan gece Çekoslovakya'ya girip Bohemya'yı Moravya Protektorası ismiyle Almanya'ya bağlamışlardır. Aynı günlerde Maca- 
ristan da Almanya'nın onayı ile Rutenya'ya girmiş ve burası bağımsızlığını ilan etmiştir (Altuğ, 1994: 9, Armaoğlu, 1996: 288).

Aslında tüm dünya gibi Türkiye de Almanya'nın Çekoslovakya ile ilgili planlarını tahmin edebiliyordu. Almanya'nın Ankara Büyükelçisi Keller, Dışişleri Bakanı Aras ile 19 Şubat 1936 tarihinde yaptığ1 görüşmeyi Berlin'e bildirirken, Aras'ın Çekoslovakya'ya muhtemel bir Alman saldırı planının varlığından söz ettiğini yazmıştır (Koçak, 2013:132). Prag'ın işgaline kadar amacı Almanları tek bir devletin s1nırları içerisinde toplamak olan Alman politikası, Çekoslovakya'nın işgaliyle birlikte Hayat Sahası ve Yeni Düzen safhalarına geçmiştir. Almanya'nın Balkanlara dayanması ve Hayat Sahası'nın sınırlarının belirsizliği antirevizyonist devletleri endişeye sevk etmişti. Balkanlarda Almanya'nın yarattığı endişe Türkiye'de de kuvvetli bir şekilde hissedilmiş, Türkiye, Alman politikalarına şüphe ile bakmaya başlamıştır (Koçak, 2013:134). Almanya'nın Çekoslovakya'yı işgalden sonra 23 Mart 1939 tarihinde Romanya'ya baskı uygulayarak, ekonomik bir anlaşma imzalamaya mecbur etmesi, Türkiye'de Alman revizyonizminin Balkanlara ulaştığı endişesine neden olmuştur (Sönmezoğlu, 2011: 321). Bu durum İngiltere ve Fransa tarafindan da endişe ile karşılanmış, iki devlet 13 Nisan 1939 tarihinde Yunanistan ve Romanya'ya bağımsızlıkları için garanti vermişler, bu teklif aynı gün Türkiye'ye de yapılmıştır (Sönmezoğlu, 2011: 321).7 Nisan 1939 tarihinde İtalya'nın Arnavutluk'u işgali Türkiye'nin tedirginliğini daha da artırmış, Başbakan Refik Saydam Almanya'nın Ankara Büyükelçiliği’nde görevli diplomatlardan Kroll'a işgalin Almanya'nın İtalya'nın yanında Türkiye'ye karşı aldığı bir tutum olarak algılandığını söylemiştir (Sönmezoğlu, 2011: 321-322). Yine işgalden birgün sonra Türkve Romen dişişleri bakanları Balkanlardaki güvenlik sorunlarını görüşüp işbirliği yollar1 aramışlardır (Sönmezoğlu, 2011: 321-322, 333-334, Vakit 9 Nisan 1939: 1,6, Akşam 9 Nisan 1939: 1,7).

4 Mayıs 1939'da Dışişleri Bakanlığı tarafından hazırlanan genelgede dış politikayı yeni duruma uydurma zorunluluğu ortaya konulmuştur. Genelgede Türkiye'nin başından beri Almanya'nın dinamizmini ve İtalya ile yakınlaşmasını tarafsızlıkla karşıladığı ve Almanya ile olan dostluk ve ekonomik ilişkilerini Almanya'nın büyük devletlerle gerginleşen ilişkilerine rağmen sürdürdüğü yazılmıştır. Türkiye'nin, 
Almanya'nın ırki genişlemesini Milletler Cemiyeti fikrinin iflasından beri oluşan şartların bir gereği olarak algıladığı vebu şekilde Almanya'ya dostluğunu gösterdiği vurgulanmıştır (Koçak, 2013: 134135). Bu politikanın Münih Konferansı sonrasında da devam ettiğinin belirtildiği genelgede Çekoslovakya'nın işgaliyle durumun farklılaştığı ortaya konulmuştur. Genelgede Hitler'in ırksal görüşlerinin hayat sahası görüşüne evrildiği ve diğer devletleri genişlemenin sınırları konusunda tedirgin ettiği ifade edilmiştir. Buna rağmen Türkiye'nin Çekoslovakya'nın işgalini bile ilişkileri etkileyecek bir gelişme olarak görmediği, fakat asıl endişe edilenin Almanya'nın Romanya'ya imzalattırdığı ekonomik anlaşma ve İtalya'nın Arnavutluk'u işgali olduğu vurgulanmış, Mihver Devletleri'nin hedeflerinin artık görülür olduğu belirtilmiştir. Almanya'nın ekonomik yükselişini İtalya ile yaptı̆̆ 1 stratejik işbirliğiyle perçinlediği ve bunun batıyı uyuşukluktan çıararak harekete geçirdiği vurgulamış, Balkanlara kuzeyden ve batıdan gelecek saldırıların Türkiye için tehdit olduğu belirtilmiştir. Genelgede Balkan Antantı'nın zayıflatılması, Bulgaristan'ın revizyonist politikaları, ekonomik esareti genişletme çabaları ve askeri işgaller karşısında güvenlik önlemleri almakta gecikmenin ülkeyi telafisi edilemez durumlara sokacağ1 belirtilmiştir (Koçak, 2013: 135).

Kroll, 18 Mart 1939'da Dışişleri Bakanlığı Genel Sekreteri Numan Menemencioğlu ile bir araya gelmiş ve Menemencioğlu, Çekoslovakya'nın işgaliyle birlikte Almanya'nın Balkanlar politikasında yeni bir dönemin başladığı tespitinde bulunmuştur. Menemencioğlu, Balkanların coğrafi ve ekonomik olarak Almanya'nın hinterlandı ve ikmal alanı olarak kullanması için çaba göstereceklerini açıklamış, bu konudaki tek şartlarının Almanya'nın Balkan devletlerine ideolojik dayatma yapmaktan vazgeçmesi olduğunu söylemiştir. (Koçak, 2013: 135-136). Menemencioğlu'nun Kroll'a söyledikleri Türkiye'nin Almanya'nın Balkanlara her açıdan nüfuz ettiği gerçeğini kabullendiğini göstermektedir. Zaten Çekoslovakya'nın işgaline büyük devletlerin bile nasıl tepki vereceklerini bilemedikleri bir dönemde Türkiye'nin Almanya'yı karşısına alacak bir politika takip etmesi beklenemezdi. Almanya ve İtalya'ya karşı açıktan gösterilecek tepki Türkiye'yi bu devletlerin hedefi yapabilirdi. Bu şekilde ölçülü bir tepki ile Türkiye hiç olmazsa Balkan devletlerinin ideolojik olarak Mihver grubuna kaymalarına engel olmak istiyordu. 
Türkiye ile Fransa arasında başlayan ittifak görüşmeleri Almanya tarafından Türkiye'nin tarafsızlık politikasının ihlali olarak yorumlanmış, yine Almanya, politikalarıyla ilgili bazı gazetelerde çıkan haberlerden duyduğu rahatsızlı̆ı Türkiye'ye iletilmiştir. Fakat aynı günlerde İngiltere'nin Ankara Büyükelçisinin Dışişleri Bakanı Rüştü Saraçoğlu ile yaptığı görüşme Almanya'yı rahatlatmıştır. Büyükelçi, Saraçoğlu'na Romanya'ya bir saldırı durumunda Türkiye'nin tavrını sormuş, Saraçoğlu da Balkan Antantına göre Romanya ancak bir Balkan devletinin saldırısına uğrarsa Türkiye'nin yükümlülükleri gereği askeri yardım yapacağını söylemiştir. Yine Türkiye, İngiltere ilearasındaki dostluğun Almanya ve İtalya'ya karşı birlikte savaşa girmeyi gerektirmeyeceğini de vurgulamıştır (Koçak, 2013: 136-138). Fakat Çekoslovakya'nın işgaliyle iyice belirginleşen endişeler Türkiye'yi İngiltere ve Fransa'ya ister istemez yakınlaştırmış ve Türkiye'nin Almanya ve İtalya'nın saldırgan politikalarına karşı bir politika değişikliğine gittiği 12 Mayıs 1939'da Türk- İngiliz, 23 Haziran 1939'da ise Türk Fransız ortak deklarasyonlarıyla açıklanmıştır (Tekeli ve İlkin, 2013: 71).

Görüldüğü üzere Almanya'nın Balkanlara yaklaşması, Macaristan'ın önünü açıp, Romanya'yı kontrolüne almak istemesi ve İtalya'nın Arnavutluk'u işgali Türkiye'yi önlemler almak zorunda bırakmıştır. Bu aşamada Türkiye hem Fransa ve İngiltere ile görüşmelerehem de Balkan Antantını ön plana çıkarmaya çalışmıştır. Fakat Antant, Balkanlara dışarıdan bir devlet tarafından yapılansaldırıda, imzacı devletlerin yardımlaşmasını öngörmediği için bir Alman veya İtalyan saldırısına karşı yapabileceği bir şey yoktu. Bunun için Türkiye Fransa ve İngiltere ile görüşürken bile Almanya'ya garantiler vermeye devam etmiştir. Dolayısıyla Türkiye 1924 yılından beri ilişkilerini yoğun bir şekilde devam ettirdiği Çekoslovakya'nın işgaline, kendi güvenliği için bir tepki vermemiş, hükümet bu konuda iç değerlendirmeler yapmışsa da bunlar ve benzerleri kamuoyu önünde paylaşılmamıştır.

\section{Sonuç}

Türkiye ve Çekoslovakya, iki savaş arası dönemde uluslararası ilişkilerde oldukça benzer politikalar takip etmişlerdir. Her iki ülke de öncelikle içeride güçlü bir devlet otoritesi ve ekonomik yapı kurmak için uğraşmışlar, dış politikada da savaştan sonra kurulan Avrupa statüsünün 
devamı için büyük ölçüde İngiltere ve Fransa ile uyumlu, antirevizyonist bir dış politika izlemişlerdir. Türkiye ve Çekoslovakya'nın içeride otoritelerini sağlayıp, ekonomilerini güçlendirerek büyük devletler haline gelmeleri için istikrar ve barış ortamı en önemli şarttı. Buna karşın Birinci Dünya Savaşı'ndan sonra oluşan Avrupa statüsünü kabul etmeyip tekrar iddialı devletler haline gelmek için revizyonist politikalar takip eden Almanya, İtalya, Macaristan ve Bulgaristan Türkiye ve Çekoslovakya için en büyük tehlikeyi oluşturuyorlardı. Almanya ve Macaristan'ın Çekoslovakya toprakları üzerindeki hak iddiaları bu devleti Romanya ve Yugoslavya ile ittifaka mecbur bırakmış, Fransa da bu üç devletin en önemli müttefiki olmuştur. Yine Bulgaristan'ın Balkanlar, İtalya'nın Balkanlar ve Akdeniz üzerindeki iddiaları ve Almanya'nın Balkanlara ilgisi Türkiye'yi büyük oranda endişelendiren ve önlemler almaya iten gelişmelerdi. Dolayısıyla her iki devlet de benzer tehditler karşısında benzer politikalar geliştiriyorlardı. Bu durum iki devletin yakınlaşmasını kolaylaştırmış, imzalanan Dostluk Antlaşmasıyla başlayan ilişkiler birçok alanda yapılan ikili anlaşmalarla devam etmiştir. Bu dönemde iki ülke ilişkileri en fazla ticari sahada yoğunlaşmış, her iki ülke birbirlerinin en önemli dış ticaret ortaklarından biri durumuna gelmişlerdir. İki devlet bu şekilde geliştirdikleri uyumlu ilişkilerle Avrupa'nın tarih boyunca en zor dönemlerinden biri olan iki savaş arası yıllarda kıta ve dolayısıyla dünya barışına katkı yapmışlardır. Türkiye Çekoslovakya ilişkilerinin büyük oranda sorunsuz devam etmesinde her iki devletin başında bulunan ve iki savaş arası dönemin saygın ve büyük devlet adamları arasında kabul edilen cumhurbaşkanlarının büyük payı vardır. Türkiye'de Atatürk, Çekoslovakya'da ise Masaryk ve Beneş ülkelerinin bağımsızlığında çok önemli rolleri olan kurucu liderlerdi. Bu liderler iki savaş arası dönemde Avrupa'nın gittiği noktayı çok iyi okuyabilmişler ve devletlerinin dış politikalarını buna göre şekillendirmişlerdir. Birbirlerini çok iyi anlayıp birbirlerine saygı duyan bu liderler sürekli temas halinde olup iki ülke ilişkilerinin ileri seviyelere taşınması için büyük çaba sarf etmişlerdir.

Türkiye ikili ilişkilerinde önemli bir sıkıntı yaşamadığı ve her alanda iyi ilişkiler sürdürdüğü Çekoslovakya'nın Almanya tarafından parçalanması ve işgali karşısında derin bir endişe yaşamıştır. Türkiye Çekoslovakya gibi Almanya ve İtalya'nın yayılmacı politikalarının hedefi olabilir ve İngiltere ve Fransa Avrupa'nın ortasındaki 
Çekoslovakya'nın işgalini seyrettikleri gibi Türkiye'nin de benzer bir durumla karşılaşması halinde olaya müdahale etmeyebilirlerdi. Bunun için Türkiye büyük bir haksızlık olarak gördüğü Çekoslovakya'nın parçalanmasına Almanya'nın tepkisine neden olabilecek bir şekilde ses çıkarmamış, fakat muhtemel gelişmelere karşı önlemler almaya başlamıştır. Bu konuda Almanya ve İtalya'nın Balkanlarda daha fazla ilerlememesi için harekete geçen Türkiye, Almanya ve İtalya'yı daha fazla ilerlememeleri için diplomatik olarak ikaz ederken, antirevizyonist Balkan Devletleriyle Balkanların güvenliği, İngiltere ve Fransa ile ittifak anlaşmaları yapmak için görüşmelere başlamıştır. Revizyonist devletlerin saldırılarına karşı coğrafi ve sosyal olarak Çekoslovakya'dan çok daha fazla avantajlı olan Türkiye bunu ve diplomasiyi çok iyi kullanarak İkinci Dünya Savaşı'nda 1938 ve 1939 yılında Çekoslovakya'nın başına gelenleri yaşamamıştır. 


\section{Kaynakça}

\section{Kitap ve Makaleler}

Akdevelioğlu A., B. Oran, Ç. Erhan, E. Tellal, G. Alpkaya, İ. Uzgel, K. Özersay, M. Fırat, M. Aydın, Ö. Kürkçüoğlu, S. Baykal ve T. Arat. (2001). Türk dış politikası Kurtuluş Savaşı'ndan bugüne olgular, belgeler, yorumlar Cilt I: 1919-1980. B. Oran (Ed.). İstanbul: İletişim Yayınları.

Altuğ, Y. (1994). Çekoslovakya sorunu. Ankara: Türk Tarih Kurumu Basımevi.

Aras, T. R. (2003). Atatürk'ün dış politikası. İstanbul: Kaynak Yayınlar1.

Arıboğan, Ü.,G. Ayman ve B. Dedeoğlu (2010). Uluslararası ilişkiler sözlüğü (4. Bask1). F. Sönmezoğlu (Der.). İstanbul: Der Yayınlar1.

Armaoğlu, F. (1996). 20. yüzyıl siyasi tarihi Cilt 1-2: 19141995 (11. Baskı). İstanbul: Alkım Yayınevi.

Cevizliler, E. ve A. S. Öncü (2013). Birinci Dünya Savaşı'ndan sonra Avrupa barışı için önemli bir adım: Locarno Konferansı. Karadeniz Sosyal Bilimler Dergisi, Sonbahar, Y11 5, 9, 307-340.

Esmer, A. Ş. (1953). Siyasi tarih (1919-1939). Ankara: Siyasal Bilgiler Fakültesi Yayınları.

Jelaviich, B. (1987). Modern Austria Empire\&Republic, 1800-1986. Melbourne: Cambridge University Press.

Kennedy, P. (2001). Büyük güçlerin yükseliş ve çöküşleri (16. yüzyıldan günümüze ekonomik değişim ve askeri çatışmalar). (Çev.: B.Karanakçı). İstanbul: Türkiye İş Bankası Kültür Yayınları.

Kissinger, H. (2000). Diplomasi (8. Bask1). (Çev.: İ. H. Kurt). Ankara: Türkiye İş Bankası Kültür Yayınları.

Koçak, C. (2013). Türk Alman ilişkileri (1923-1939) iki dünya savaşı arasındaki dönemde siyasal, kültürel, askeri ve ekonomik ilişkiler (2. Bask1). Ankara: Türk Tarih Kurumu Yayınları.

Langlois, G., J. Boismenu, L. Lefebvre veP. Regimbald (2000). 20. yüzyıl tarihi. (Çev.: Ö. Turan). İstanbul: Nehir Yayınları. 
Lee, Stephen J. (2002). Avrupa tarihinden kesitler 1789-1980. (Çev.: S. Aktur). Ankara: Dost Kitapevi Yayınları.

Macmillan, M. (2004). Paris 19191919 Paris Barış Konferansı ve dünyayı değiştiren altı ayın hikâyesi. (Çev.: B. Dişbudak). Ankara: Odtü Yayıncilık.

Ökçün, A. G. ve A. R. Ökçün (1974). Türk antlaşmaları rehberi (19201973). Ankara: Ankara Üniversitesi Siyasal Bilgiler Fakültesi Yayınları.

Potyemkin V., S. Baruşin, A. Efimov, E. Kosminski, İ. Mintz, A. Naroçnitski, A. Pakratova, V. Sergeyev, S. Skazin, V. Kvotsov, N. Koltchanovsky ve E. Tarle. (2009). Uluslararası ilişkiler tarihi -diplomasi tarihi- 4.(Çev.: A. Tokatlı). İstanbul: Evrensel Basım Yayın.

Renouvin, P. (1982). 1. Dünya Savaşı 1914-1918 (3. Baskı). (Çev.: A. Cemgil). İstanbul: Altın Kitaplar Yayınevi.

Sander, O. (2008). Siyasi tarih 1918-1994 (17. Bask1). İstanbul: İmge Kitapevi Yayınları.

Seyidoğlu, H. (2009). Uluslararast iktisat teori politika ve uygulama. İstanbul: Güzem Can Yayınları.

Şimşir, B. (1993). Atatürk ve yabancı devlet başkanları, C. I. B. N. Şimşir (Haz.). Ankara: Türk Tarih Kurumu Basımevi.

Sönmezoğlu, F. (2011). İki savaşs sırası ve arasında Türk dış politikası. İstanbul: Der Yayınlar1.

Tekeli, İ. ve S. İlkin (2013). Dış siyaseti ve askeri stratejileriyle İkinci Dünya Savaşı Türkiye’si C. I. İstanbul: İletişim Yayınları.

Uçarol, R. (2010). Siyasi tarih (1789-2010) (8. Baskı). İstanbul: Der Yayınları.

Üçok, Ç. (1978). Siyasal tarih (1789-1960). Ankara: Ankara Üniversitesi Hukuk Fakültesi Yayınları.

Yavuz, A. (1976). Türkiye Cumhuriyeti'nin akdettiği milletlerarası andlaşmalar (20Nisan 1920-1 Temmuz 1976). Ankara: Dişişleri Bakanlığı Yayınları. 


\section{Arşivler}

\section{Başbakanlık Cumhuriyet Arşivi}

BCA, 30..10.0./218.474..14., Belge No:1.

BCA, 30..10.0.0/ 129.930..2., Belge No:1.

BCA, 30..18.01.02/1.11..15., Belge No:1.

BCA, 30..18.01.01/017.94..3., Belge No:1.

BCA, 30..18.1.1/ 17.89..7., Belge No:1.

BCA, 30..18.01.01/020.55..13., Belge No:1.

BCA,30..18.01.01/26.67..7., Belge No:1.

BCA, 30..18.01.01/26.67..8., Belge No:1.

BCA,30..18.01.02/3.23..7., Belge No:1.

BCA, 30..18.01.02/ 45.34..9., Belge No:1.

BCA, 30..18.01.02/43.13..16., Belge No:1.

BCA, 30..18.01.02/ 63.23..17., Belge No:1.

BCA, 30..18.1.2/82.8..9., Belge No:1.

BCA, 30..18.1.2/84.62..13., Belge No:1.

BCA, 30..18.1.1/022.75..7., Belge No:1.

BCA, 30..18.01.02/ 11.40..9., Belge No:1.

BCA, 30..18.01.02/ 18.15..4., Belge No:1.

BCA, 30..18.1.2/ 28.37..18., Belge No:1.

\section{Gazeteler}

\section{Akşam}

Türkiye Çekoslovakya Ticaret Anlaşması, 13 Mayıs 1936, s.2

Çekoslovakya İle Ticari Münasebetimiz Genişliyor, 7 Nisan 1938, s. 2 Hariciye Vekilimizle Rumen Hariciye Vekili Arasında Görüşmelere Başlandl, s.1,7

\section{Resmi Gazete}

20 Nisan 1925,s. 99.

12 Ocak 1928, s.4621- 4624. 
22 Ocak 1928, s. 4662-4667.

6 Nisan 1931, s. 371-377.

5 A ğustos 1931, s.727-728.

9 Теттиz 193, s.1695-1697, 1699-1702.

18 Şubat 1937, s.7698.

22 Nisan 1938, s. 9733-9736.

28 Haziran 1938, s. 10112.

28 Şubat 1947, s. 11942.

\section{Tevhid-i Efkâr}

Türkiye Çekoslovakya Ticaret Ahidnamesi İmzalandl, 12 Ekim 1924, s. 2

\section{Ulus}

Türkiye Çekoslovakya Ticaret Anlaşması İmzalandl, 13 Mayıs 1936, s. 2

\section{Vakit}

Romanya Hariciye Nazırı Dün Şehrimize Geldi, s. 1,6

\section{Vatan}

Türkiye Çekoslovakya Muahedesi İmzalandı,12 Ekim 1924, s. 3

\section{Zabit Cerideleri}

TBMM Zabit Ceridesi (1975), Devre II, İctima Senesi II, c.10, (1 Teşrin-i Sani 1340 Tarihli Birinci İctimadan 4 Kanun - Evvel 1340 Tarihli Onaltıncilictimaa Kadar), TBMM Matbaası, Ankara.

TBMM Zabut Ceridesi, Devre 3, İtima 2, c. 12, (18 Mayls 1929 Tarihli Altmış Altıncı İnikattan, 3 Haziran 1929 Tarihli Yetmiş Altıncı İnikata Kadar), TBMM Matbaası, Ankara.

\section{Resmi Yaymlar}

1925 Senesine Mahsus Ticaret-i Hariciye İstatistiki(1928), Devlet Matbaasiİstanbul.

Harici Ticaret İçin Ylllık İstatistik Yll 1926 Kısım II 1(929), Hamit Matbaası İstanbul 
Harici Ticaret İçin Yıllık İstatistik Yll 1927 Kısım II (1929), Ankara.

Harici Ticaret İçin Yıllık İstatistik Yıl 1928 Kısım II (1930), Cumhuriyet Matbaas1, Ankara.

Harici Ticaret İçin Yıllık Istatistik Yıl 1929 Kısım II (1931), Devlet Matbaas1, Ankara.

Harici Ticaret İçin Ylllık İstatistik Yll 1930 Kısım II (1932), Hamit Matbaası, Ankara.

Harici Ticaret Yıllık Ístatistik Yıl 1931 Kısım II(1934), Matbaacılık ve Neşriyat T.A.Ş Ankara.

Harici Ticaret Ylllı Ístatistik Yıl 1932 Kısım II (1934), Devlet Matbaas1, Ankara.

Harici Ticaret 1933 Ylllık İstatistik Kısım 2 No 1(1935), Devlet Matbaas1, İstanbul.

Harici Ticaret Ylllık İstatistik 1938 Kisım- 2(1939), Mehmet İhsan Matbaası, Ankara. 